\title{
Lingual Deconstruction of Children's Poem in Persian and English Languages
}

\author{
Saloome Rostampour ${ }^{1}$, Maryam Jalali2 \\ ${ }^{1}$ Islamic Azad University (IAU), Islamshahr Branch, Tehran, Iran \\ ${ }^{2}$ Department of Persian Language and Literature, Shahid Beheshti University, Tehran, Iran \\ Email: jalali_1388@yahoo.com
}

Received 29 February 2016; accepted 25 April 2016; published 28 April 2016

Copyright (C) 2016 by authors and Scientific Research Publishing Inc.

This work is licensed under the Creative Commons Attribution International License (CC BY).

http://creativecommons.org/licenses/by/4.0/

(c) (i) Open Access

\begin{abstract}
Poetic sentences words are placed unlike other sentences, besides each other in a special way, so that their lingual role is not the tool-oriented one to transfer message to the audience, but have a higher role. The arrangement of lexical poetic in sentences is quite symbolic and deconstructive. The poets of any society create new and innovative sentences with disrupting the common structure of the language. Innovation of new sentences or words in any language is not exclusive for the adult's poems, and also the children poets, considering their range of audience, try to deconstruct certain words or sentences to generate innovations in the child's poetry language. In this article, it has been tried that the "content analysis" method is used. After noting down the relevant references, the author has strived to analyze the same. The achievement of this study is to examine the manner of deconstruction of words and sentences in Persian and English language concerning children's poem.
\end{abstract}

\section{Keywords}

\section{Child Poem, Marked Word, Grammatical Deconstruction}

\section{Introduction}

"Poem" is unusual collocation lexical in the sentence. Unlike other types of language sentences, lexicon in poetical sentences is conducted in a certain way that their lingual role is not interfacing or contractual to transfer the message of the addressor to the audience, but has a higher role; i.e. they are not merely worded in this certain manner to express a mental, sentimental or informing message of the addressor, but are in order for the sake of excellence of the addressor's message in a collection known as "sentence”. Therefore, "poem” is known as the lean child of language. Unusual lexical collocation creates special structure of grammar in poetic sentences. 
Grammar poetry is formed based on the grammar of any language, but the definition of its nature is very different with basic grammar.

Poetic features in children's or adults' literature is equal. It is seven years that, the field of children literature has been entered in Iranian universities; for this reason the criticism of children's poems is done in Iran [1]. This issue has created the need to write such an article.

The knowledge of grammar is global and it is similar in all languages. Due to the similarity and inherent nature of this field of knowledge, Chomsky planned a "Universal Grammar" (UG) for all the languages. "UG" is referred to certain principles and rules that any speaker of any language knows [2]. According to Chomsky's theory, the global and common features are commonly available in all languages. Evidently, these common characteristics have quite limited principles, which are inherently born as lingual talent with the children [3]. "UG" is a scientific theory and not a humanistic behavior which is dialed with the structure of human mind [2]. According to Chomsky's "UG”, all the languages are fundamentally based on a single model. He believes that the similar conformity of the language on a single model is not due to the existence of common historical roots or communicative requirements of the speakers, but is due to the language' mental power characteristics [4] [5].

The "UG" theory is in conformity to all the realities realized concerning the languages. In most of the constituent languages grammatical subject is in priority to the grammatical object [6]. The constituent \& serialization principle (CSP) is an absolute global principle. Such serialization is an immovable and universal principle. A grammar which is compiled based on such rules is called "Core Grammar" (CG). According to the "UG", any lingual features which have a dominant form based on the statistical values in language are known as "unmarked". The aim of "unmarked" phenomenon is a feature which is in conformity to the grammar global. There is a "marked phenomenon" against the "unmarked" phenomenon. Any phenomenon which is against a global principle and is exceptional in a certain way is considered as "marked". In fact, "being marked" means being distant from the neutral type of a global principle. The more distant from "UG", the more marked the resulted grammar will be. In fact, "marked” grammar is an irregular or abnormal grammar. Based on the Chomsky's "UG" theory, if any rule will not be as per the general and global lingual rules, then such principle is known as a "marked" or marginal rule [7]. "Marked" and "unmarked" are applicable in all the lingual analysis levels; e.g. in Persian language, the plural signs include "hā/ān", while in English it is "s"; e.g.:

In Persian: doxtar: doxtarhā/doxtarān

In English: girl: girls

In both Persian and English, there are certain words which have no plural form, but are used in plural meaning [8] [9]. In fact, they have been used unlike the general principle of plural forms of these two languages. Therefore, they can be considered as "marked" words; e.g.:

In Persian: mardom

In English: people

Schlegel classified the world languages based on the structure of their existing to three classes "isolating", "Agglutinating" and "Inflected". In Isolation's languages the words don't have any internal word structure construction. In Agglutination languages the words have a few morphemes which are distinguished easily and every morpheme has a grammatical category. In Inflecting languages the words have Construction of internal word changes. So that looks vaguely morpheme boundary [10] [11]. In this classification the certain language subset of possible rules in the "Core Grammar" is specified. The main or core part of the sentence in any language is the verb of such sentence. However, the placement of verb in the sentence is different in various languages. For instance in "Inflected" language such as Arabic, the verb is placed in the beginning of the sentence: (yazhabo al rajol) [12]. Even it is possible that the placement of verb varies among the languages of a certain tier. For example in Persian language, the verb is placed at the end part of the sentence and in English language; the verb is placed at the second part of the sentence, respectively:

Persian: "Oue sib mixurad"

English: "He eats the apple"

In fact, the syntactic "the constituent\& serialization" in the Persian "unmarked" sentences is "subject + object + verb (SOV)" while in English it is: subject + verb + object (SVO). The syntactic "the constituent \& serialization" of the words in the sentences of any language has a certain discipline. Whenever such discipline is dis- 
torted, the resulted sentence shall be marked in comparison to the primary basic sentence. For instance in Persian, the exemplified sentence "Parichehr laid the flower in the flowerpot" is an "unmarked" sentence, while it shall be considered as a "marked" sentence in case of being expressed in one of the following forms:

"The flower was laid in the flowerpot (by Parichehr)".

"In the flowerpot the flower was laid (by Parichehr)".

"Laid in the flowerpot the flower".

Whatever, a sentence would be more "marked". It is closer to the poetic nature will be. The poets derange the main structure of the sentence for the sake of affecting more the audience. Through disrupting the sentences grammatical structure they deconstruct. For example, in Persian language, a poet changes the position of the verb in the sentence and places it in the beginning or middle of the sentence in which case his resulted sentence shall be a "marked" sentence; e.g.:

“man midunam/moYa e xāb/pišam miāyad māmān joonam/nāz mikone mooy e Mano” [13].

The fourth sentence in the above mentioned example is "marked", of which the "unmarked" form is as per the following:

"Mooy e mano nāz mikone".

Deconstructing in English sentences is in another manner. The English poet cannot deconstruct the existing discipline in English sentence formation to innovate new sentences. For instance, unlike his Persian peer, he cannot change the place of verb in the sentence. The verbs of his sentences shall definitely be given after the subject, as unlike Persian verbs, the English verbs have no "Ending" and shall therefore be placed after subject so that their person and count are known.

"I will arise and go now, and go to Innis free,

And a small cabin build there, of clay and wattles made:

Nine bean-rows will I have there, a hive for the honeybee,

And live alone in the bee-loud glade,..." "William B Yeats" [14].

In the sentences of the above poem sentence, the words "arise, go, build, go" are the verbs which have been given exactly after "I" as the subject. What has signed these sentences "marked" or in lingual term, is that their subject has been given only once in the beginning of the first sentence. As it is seen in the second line of the poem, the object "a small cabin" has been given before the verb which also causes prominent and "marked" the sentence. This poetical trick can be seen in children's poets:

"I had a little secret/And I told a friend of mine/I made her promise not to tell

I thought it would be fine/But then she told somebody else/And they told someone too/Then each of them told others/And it grew, and grew, and grew" "Kenn Nesbitt" [15].

The other trick of the poets in their poetry is disrupting the sentence structure. Such deconstruction is appeared based on the nature of any language. For instance, Arabic is one of the "Inflected" languages; i.e. the words in this structure of this language are appeared through "Morphology". Therefore, in case a new word is emerged in the language, such word shall be made based on the Arabic language word making system. The word making structure basis in Persian and English is also as per their nature. These two belong to the "Agglutinating" languages; i.e. the words of these languages are emerged by adding "Affix" in the beginning, middle and ending of the word items. The adding affixes to the lexical stems in Persian or English sometimes change their meaning or grammar context. Sometime through disrupting the lexical structure the Persian poets innovate new words in their poems; e.g. they link a affix to be linked to the noun, to adverb, pronoun or adjective:

"Guft Kūčōlō kōjā mīrī/e fōt konam/zūd mīmirī/pašah parīd yavāšakī” [16].

The word "Yavāšak $\vec{\imath}$ " is a poetic and innovative word, as the suffix "K $\vec{\imath}$ " in Persian language links to the noun and makes a "adjective or adverb", e.g. "Dūzdkī $\rightarrow$ dūzd + kî̀". However, in "yavāšak $\vec{\imath}$ ", the suffix "k $\vec{\imath}$ " has linked to adverb and again it has been made an "adverb" from an "adverb". In fact, the poet has marked it through disrupting the lexical structure. This deviation is seen in English language too: 
"Christopher robin goes/Hoppity, hoppity/Hoppity, hopity, hope/Whenever I tell him/Politely to stop it, he/ Says he can’t possibly stop. /If he stop hopping He couldn’t go anywhere, /Poor little Christopher/couldn’t go anywhere" [17].

The suffix "ity" in "hoppity" in above mentioned example has not used in its rightful place. This suffix is a noun suffix in English language; but the poem has used it for building an adverb.

Also sometimes in order to apply "marked" word in the poem, the poet uses a certain word which is merely applicable and meaningful for a certain group of people, e.g.

“Māšin e xāleh pīšìibāz bā YāYān Yōn ōmad/bā šiššeh šekasteh/če darb o dāYūn ōmad” [18].

In the above example, the words "pīšs̀" and "Yā Yān Yōn" are the expressions which are known for those who use or are familiar with the meaning of them.

\section{Description of Lingual Deconstructions}

The contemporary children poets understood that like adult's poetry, the poetic subjects for the children are various. They derange the grammatical structure in sentences to affect more their audience and sometimes use "marked" words in their poetry. The important difference is that; their poetry language is very simple.

"Daryā dāre be man migeh/Biyā julō natars digeh/Julō miram yavāš yavāš" [19].

The important and thinkable point achieved by the child poets during the modern era is that due to the insufficient capability of their audience in the language, they shall limit their "lexical treasure" while authoring their childish poems. Due to their audience special characteristics, the poets cannot use "marked" sentences or words frequently and should relearn their "native language" along and simultaneously with the children. For instance, they cannot innovate new words in Persian language through abnormal mixing the affixes with lexical stems and shall merely use those "marked" words in their poetry of which their meanings are clear and well-known for the audience:

"Bad midavam/Miram xune/Miram sourāy e sobhaneh/Hām mikonam nōn ō panir” [20].

In the above fragment, the expression "Hām Kardan" means "to eat". This word is meaningful only for children and especially those of five years of age and younger. Evidently, the childish "lexical treasure" has not been created by the adults, but the children create them.

"Nināsh nāsh, nināsh nāshe/Otā če rixt ō pāše/Nini dāre mirayse/Jašne arūsakā še” [21].

In the said fragment, the two words "Nināsh" and "Nini" are childish "marked" words. These mentioned features are also seen in English language childish poems. Also the English language child poet has limited lexical treasure and used certain words in his poems which may be understood by his audience. Using simple and repetitive words in poetic sentences are from amongst the English language childish poems [22].

"Baa, baa, black sheep/Have you any wool/Yes Sir, yes sir/Three bags full/One for the master/One for the dame/And one for the little boy/Who lives down the lane".

Also, English language child poet uses the words made by children in his poems:

"When the boat comes in/You shall have a fishy/In a little dishy/You shall have fishy/When the boat comes in".

In the above fragment, "fishy, dishy" are from amongst the words made by the children. Considering their structure, it is seen that the main feature of these words is their musical nature. Children may make mental connection to the musical types of the words and understand and memorize them better. Like the native speaker of any society the children innovate, their nursery words. During their first two years of life, they try learning their "native language" by repeating meaningful or meaningless sounds or syllables. Repeating lingual syllables create a certain type of intonation which is meaningful for the children. For instance, repeating "Mā̄" syllable in Persian language reminds the word "Mādar" (mother). However, repeating syllable is not always this much clear.

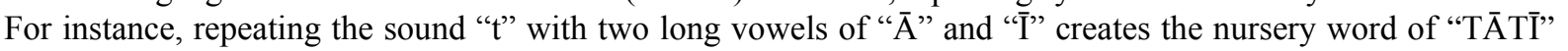
means "walking". In the beginning of their talking, children innovates "nursery words" to name their environ- 
ment's objects and concepts. The considerable point in these words is the existence of intonation. Children highly consider the intonations; such consideration is so that sometimes the words real meanings and contexts are sacrificed for the sake of their structure. For instance, repeating the syllable " $\gamma \bar{a}$ " in the form of " $\gamma \bar{a} \gamma \bar{a} \bar{a}$ " means "food". This word has been given in none of the Persian dictionaries; e.g.

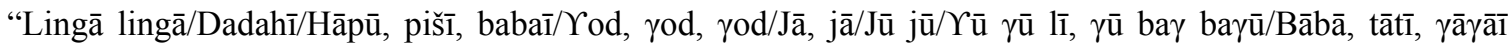
/Māmān, mameh, lālā̄”’.

In the above fragment, the poet has been able to collocation the "nursery words" besides each other and both create meaningful text for his audience and make them pay attention to their environment. Also the English language poet has managed to combine the meaningless yet musical "nursery words" besides meaningful ones to create a musical context to motivate his audience:

"Hey, diddle, diddle

The cat and the fiddle

The cow jumped over the moon

The little dog laughed

To see such fun

And the dish ran away with the spoon”.

Usually, the children use "marked" words only during their first five years of life. When their "lexical treasure" is enriched, their "nursery words" are not used anymore, and like other people of the society try to use common words of the language. However, the structure of children's sentence making identifies them from other people of the society. The grammatical structure of children's language is quite easy and understandable. Also this structure has been manifested into the childish poems. Like other poets, "nursery poet" tries to change grammatical rules. The method of using grammar in child poem is quite special. The first feature is that the poets try to derange the form of grammatical intonation to create musical sentence, e.g.:

“Setāre āy setāre/Dādāš jōnam dobare/Mašyām o karde pare” [23].

In the above fragment, the poet tries to change the combined verb structure to make his intonation. Through displacing the elements of such verb (verbal morpheme and the verb of compound) he has generated a good musical word in his intonation for his audience. The other point is that usually the children poets try to use spoken "oral speech" grammatical rules in their poems:

"Dādāš to hayat/Dāre barfā o/Mikoneh pārū" [24].

The verb "Dāre pārū mikoneh" (is shoveling) is present continuous, which is merely used in "oral speech" in Persian language. The form of speech in any language is the understood form for the all, and as all the people of the society use it similarly, it is quite simple without any literary ornaments. Using this poetic type, the children poet tries to get close to his audience.

The other trick is that sentence is made in Persian in two ways: either the sentence is made based on "actual verb", or it is based on "auxiliary verb". Usually the children poet of this language removes the "auxiliary verbs" of his poems. Through removing linking verb and linking the "ending" to predicate, in fact he approaches his poetic language to the speech language to enable his audiences understands better his thoughts and feelings.

"Mā bačehā/Mesl e gūlīm/Xīlī $\gamma$ ašang o topūlīm” [25].

"Discussions in children literature have become so widespread in recent two decade that one can assign various branches to it” [26]. Building children's poetry compilation of words, compounds and tracks; therefore, base of children's poetry, should be tailored to the child's understanding [27]. The words are fictitious. The words of the poem are durable. Children love and understand these words.

\section{Conclusion}

The nature of language in any society is tool-oriented. By using such tools, the people of any society may make better and more interactions. However, there are certain people in any society who do not use it as a tool, but try to apply it correctly but in a special way to excel the language of their society. The poets of any society try to 
express their feelings and thoughts in the form of poetic sentences to excel their nation's language. By disrupting their "native language" structure and rules, in the form of word or sentence, they pursue two purposes: first they strive for innovating new words and sentences to enhance their language dynamism; i.e. play a main role in revival of the language; second is that through creation of new sentences and words they extend the lexical scope of language. They create new and fresh words in the language and make their thoughts and feelings in the framework of such new words as eternal and durable.

\section{References}

[1] Jalali, M. (2015) Adaptation in Children's Literature. Taravat Publishing, Tehran, 7.

[2] Lachini, K. and Yalami, F. (1995) Chomsky’s Universal Grammar an Introduction. Islamic Azad University Scientific Publishing, Tehran, 14

[3] Torabi, M.A. (2003) Grammar; Effectiveness Criteria and Worlds. Daneshkadeh adabeyat va olum e ensani Tabriz, $46^{\text {th }}$ year, 187, $130-150$.

[4] Lachini, K. and Yalami, F. (1995) Chomsky’s Universal Grammar an Introduction. Islamic Azad University Scientific Publishing, Tehran, 87.

[5] Cook, V.J. (2007) Chomsky’s Universal Grammar. Chagini, I., Trans., Rahnamaa. Tehran.

[6] Cook, V.J. (1995) Introduction on Chomsky’s Universal Grammar. Islamic Azad University Scientific Publishing, Tehran.

[7] Torabi, M.A. (2003) Grammar; Effectiveness Criteria and Worlds. Daneshkadeh adabeyat va olum e ensani Tabriz, $46^{\text {th }}$ year, 187, 140.

[8] Torabi, M.A. (2003) Grammar; Effectiveness Criteria and Worlds. Daneshkadeh adabeyat va olum e ensani Tabriz, $46^{\text {th }}$ year, 187, 141.

[9] Sojoudi, F. (2004) Introduction to Applied Sign. Ghesseh Press, Tehran.

[10] Lotfipour, S.K. (1992) An Introduction on Speech Exploration. Linguistics Magazine, 1, 9-39.

[11] Alburzivarki, P. (2013) Classify Linguistics. Amir Kabir Publishing, Tehran.

[12] The Man Is Going (Translation).

[13] Shabani, A. (2012) Collection of Young Children Poems. Touka Press, Tehran, 8.

[14] Irish Poem and Author 1865-2939. http://www.poetry4kids.com

[15] In the Yard/Is Shoveling/the Snow. http://www.poetry4kids.com

[16] Shabani, A. (2012) Collection of Young Children Poems. Touka Press, Tehran, 125.

[17] http://www.poemsforchildren.org/A-A-Milne-for-children.htm

[18] Shabani, A. (2012) Collection of Young Children Poems. Touka Press, Tehran, 94.

[19] Shabani, A. (2012) Collection of Young Children Poems. Touka Press, Tehran, 269.

[20] Shabani, A. (2012) Collection of Young Children Poems. Touka Press, Tehran, 313.

[21] Shabani, A. (2012) Collection of Young Children Poems. Touka Press, Tehran, 313-314.

[22] Rostampour, S. (2013) An Overview on Persian Grammar. Sarafraz, Karaj.

[23] Shabani, A. (2012) Collection of Young Children Poems. Touka Press, Tehran, 77.

[24] Shabani, A. (2012) Collection of Young Children Poems. Touka Press, Tehran, 77-78.

[25] Shabani, A. (2012) Collection of Young Children Poems. Touka Press, Tehran, 88.

[26] Jalali, M. (2011) New Fantastic Tale in Persian Children’s Literature Fantasy Stories Trend in Iran between 1990 and 2007. Journal of Human Sciences, 8, 841-849.

https://www.j-humansciences.com/ojs/index.php/IJHS/article/view/1445

[27] Jalali, M. (2014) Use of the Verb in the Children's Poems. 9th Congress of International Association for Promotion of Persian Language, Speech. 